\title{
"A past that has never been present": The Literary Experience of Childhood and Nostalgia
}

\section{ABSTRACT}

This essay explores the modernist aesthetic involved in creating a fictive, nostalgic, childhood experience. Evoking the experience of childhood through fiction is as close to actually reliving childhood as we can get. The author argues that it is possible to actually transport the reader into not only the idealized world of childhood, but more so into an embodied experience of childhood through the use of different kinds of narrative and stylistic configurations. In a stylistic and narratological analysis of three modernist novels, Virginia Woolf's The Waves (1931), Tarjei Vesaas' The Ice Palace [Is-slottet] (1963) and William Faulkner's The Sound and the Fury (1929), the author explores the different ways that literature can create (or re-create) the very experience of childhood through literary style. The strategies involved in establishing a fictive experience of childhood extend from narratological choices such as free indirect style, strict focalization through a child in the narrative (which implies limitations in perception and cognitive abilities, as well as in linguistic terms) to the use of a childlike temporality, the hyperbolic use of phenomena, and an emphasis of the sensorial aspects of perception.

Keywords: literary experience, childhood, nostalgia, modernism, aesthetics. 
Literature can be about nostalgia, but it can also evoke nostalgia in the reader. Similar to the Madeleine cake in Marcel Proust's À la recherche du temps perdu, these evocations can be involuntary and accidental, but they can also be the effect of a deliberate nostalgic aesthetic offering tropes, symbols and stylistics that open up the potential for the reader's nostalgia. Nevertheless, since personal nostalgia is so closely related to individual biography, these aesthetic formations can, at best, trigger biographical memories and longings in the reader, blending private nostalgia with fictive nostalgia. There are several stylistic approaches to achieve this: analeptic narration, ${ }^{1}$ free indirect discourse, anachronies in the narrative order, and the use of iterative narrative frequency, as well as established nostalgic tropes such as the ruin, shepherd, pastoral landscapes, to mention a few examples. The most resourceful trope to use, though, is that of childhood. In "'Our flame, the will-o'-the-wisp that dances in a few eyes, is soon to be blown out and will fade.' Modern Literary Nostalgia as a Death Mood" I describe how the nostalgic trope of childhood relates to nostalgia's teleological nature:

Nostalgia evoked through the use of childhood is generally achieved by addressing the world of childhood as an alternative to the present. This is done either through the use of an idealized space or time, by reinforcing its past character, or by using common symbols or representations of childhood that force the reader into the sensations of his own past childhood. (115-16)

The strength of the childhood trope is its universality: it is both private and impersonal as a literary representation. This is one of the reasons why the romantic nostalgic poets replaced the pastoral shepherd with that of the child: "We can only sympathize imaginatively with a shepherd in a pastoral; we all have memories of childhood, and thus a personal connection to a child," writes Aaron Santesso in A Careful Longing: The Poetics and Problems of Nostalgia (71). Thus, the poet is "able to engage with the reader's own nostalgia” (Santesso 71) through using a trope that irresistibly forces the reader into his own youth and childhood. The experience becomes personal, but the strategy is impersonal. Santesso convincingly situates the childhood trope as the most essential in the nostalgic, romantic poetry he investigates. The nostalgic childhood trope also includes everything associated with childhood such as children, children's games, and toys. Furthermore, Santesso writes that Schiller argued that children were

1 For an extensive analysis of analeptic narration and the application of textual memory in order to create a nostalgic reading experience, see Salmose "Reading Nostalgia: Textual Memory in The Great Gatsby." 
also associated with nature because "children were emblematic of a lost relationship with nature" (70). Nostalgic childhood tropes, then, come to symbolize nature as well.

The idea of using childhood imagery in order to create possibilities for reader associations with nostalgic domains is fairly common. A seminal example is the significant scene in J. D. Salinger's The Catcher in the Rye when Holden experiences sudden happiness watching his little sister Phoebe on the carousel. He himself does not understand why, but the whole image of the carousel, always playing the same songs, reminds him of his own childhood. Although he is not aware of it yet, this step of looking back to his own childhood with a subconscious desire is actually the first step to adulthood where this happiness will also be infused with the tragic element of nostalgia (Salinger 210-13). Holden's nostalgia can be transferred to us as readers and can trigger similar nostalgic memories trough the trigger of the carousel.

Another example of how the allusion to childhood is effective in evoking nostalgia can be found in Virginia Woolf's highly nostalgic novel To the Lighthouse. Woolf chooses to address the world and wonder of childhood through Mrs Ramsay's young son James Ramsay in order to firmly establish the nostalgic tone of her book. The book opens with a series of sensations- " $[\mathrm{t}]$ he wheel-barrow, the lawn-mower, the sound of poplar trees, leaves whitening before rain, rooks cawing, brooms knocking, dresses rustling..." (5) — that together with Woolf's rhythmic style put the reader right into the wonder of sensations of childhood.

Obviously, the genre of the children book also contains adult nostalgic elements. "Wind in the Willows," writes Fay Sampson, "is not really a children's book, but a middle class adult's nostalgia for a rural idyll, a flight from the industrial and proletarian present" (62). This adult longing is also stressed in J. M. Barrie's Peter Pan. The sadness of lost childhood, as represented by Neverland, is forcefully explained by the narrator: "On these magic shores children at play are for ever beaching their coracles. We too have been there; we can still hear the sound of the surf, though we shall land no more" (Barrie 14). The constructed and idealized childhood in some children books, thus, comes to represent both a reminder of the childhood world and a nostalgic melancholia through its for ever lostness.

As noted above, the broad use of childhood in order to evoke readers' nostalgia of their own childhood is a proven strategy. By extension, it is also possible to actually transport the reader into not only the idealized world of childhood, but more into an embodied experience of childhood through the use of different kinds of narrative and stylistic configurations. Where childhood tropes and scenes trigger our own childhood memories, the literary experience of childhood captures the very representation of these 
memories through a focalized childhood mood. This nostalgic strategy is different than, for example, the adult remembrance of childhood through Victorian children's books. In focalized childhood, the narrator and focalizer is the child itself creating an interior childhood consciousness. The potential of such an aesthetic choice, in terms of nostalgic experience, is that the engagement with the childhood world is a more embodied and sensory experience. Although the childhood experience through fiction can be similar to one's own experience, its fictive nature still creates what Maurice Merleau-Ponty has described as "a past that has never been present" (252). The fictiveness of the literary experience makes it slightly unreal, just as idealized nostalgic memories. Even if fiction can simulate childhood in a convincing manner by reverberating the sensation and perception of childhood, as we will see in the analyses in this essay, that experience is confronted by the constant reminder of its pastness through the present, adult reading situation. Hence, it is in the oscillation between the adult time of reading and the childhood experience that nostalgia emanates.

Stylistic transmediations of childhood experience into fiction, and the subsequent creation of nostalgic experiences, is parallel to the experimentation of form in modernist fiction and heightened nostalgic awareness during modernity. ${ }^{2}$ The creation of a childhood consciousness is thus a consequence of "the inward turn," modernism's focus on interior consciousness and subjective experience. Examples of modernist fiction that are constructed around ideas and concepts of nostalgia are innumerable. Some notable examples include James Joyce's Ulysses, F. Scott Fitzgerald's The Great Gatsby, Thomas Mann's Der Zauberberg, Virginia Woolf's To the Lighthouse and Mrs Dalloway, Marcel Proust's À la recherche du temps perdu, Evelyn Waugh's Brideshead Revisited, D. H. Lawrence's Lost Girl, and Malcolm Lowry's Under the Volcano. Somewhat rarer are modernist novels that engage in childhood consciousness. The three diverse, but comparable, novels that make up this analysis, Virginia Woolf's The Waves (1931), Tarjei Vesaas' The Ice Palace [Is-slottet] (1963) and William Faulkner's The Sound and the Fury (1929) will be used to exemplify how a specific, modernist literary style creates the potential for a reader experience of childhood (and by extension nostalgia). It is not my

2 For studies on the relationship between nostalgia and literary modernism see: Svetlana Boym's The Future of Nostalgia (19-32), Aaron Santesso's A Careful Longing: The Poetics and Problems of Nostalgia (72), Niklas Salmose's Towards a Poetics of Nostalgia: The Nostalgic Experience in Modern Fiction (101-08), Sylviane Agacinski's Time Passing: Modernity and Nostalgia (3-61), Karin Johannisson's Nostalgia: En Känslas Historia (125-42) and Randall Stevenson's “Not What it Used to be: Nostalgia and the Legacies of Modernism” (23-39). 
argument that these novels entirely capture the experience of childhood, only that a few scenes or sections do so. Hence, I will not deal with the novels in whole, but only sections from them. Furthermore, the three authors represented here are not selected for their considerable interest in childhood or childhood tropes; to my knowledge, with a few exceptions, their publications are not centred on childhood either as an idea or as style. They are, however, experimental in form and occasionally obsessed with nostalgia and temporality within their own experience of modernity. This nostalgic infatuation affects their content, as well as their writing style, accommodating what could be called a modernist aesthetics of nostalgia.

My definition of a literary childhood experience is the experience of childhood as an interior consciousness that is inflamed by sensations, perceptions and embodiment that simulate true childhood experience and memory. Literary childhood experience, thus, can be read as a basic combination of definitions such as childhood consciousness, the embodiment of childhood, the experience of childhood, the sensations of childhood. It is not my intention here to engage in the contemporary and appealing theoretical debate on narrative experience, built on cognitive and enactivist approaches from such diverse fields as cognitive and evolutionary psychology and neuro science; it is both too complex to develop within the scope of this essay and, as far as my own interests are concerned, not entirely relevant to my own analysis. ${ }^{3}$ Still, it might be worthwhile to discuss Marco Caracciolo's distinction between consciousness-attribution and consciousness-enactment in The Experientiality of Narrative: An Enactivist Approach. According to Caracciolo, we always attribute a consciousness to fictive characters as "an inevitable consequence of our tendency to interpret some bodily and verbal signs as expressive of consciousness" (117). This is different from when we "imagine from someone's perspective"; consciousness-enactment is about how "readers manage to experience a fictional world through the consciousness different from their own" (118). Caracciolo offers a series of triggers of consciousness-enactment that on the whole parallel my own stylistic and narratological analysis in this essay, such as internal focalization, stylistic markers, punctuation and consciousness tags (although I occasionally use a different terminology) (126). What I add to Caracciolo's theory is how these triggers operate also

3 For further reading on new theories of fictive experience, see Marco Caracciolo's The Experientiality of Narrative (2014), Alan Palmer's Fictional Minds (2004), Marco Caracciolo and Russell T. Hurlburt's A Passion for Specificity: Confronting Inner Experience in Literature and Science (2016), and Monika Fludernik's Towards a "Natural" Narratology (1996) where she develops the concept of experientiality. 
within the biographical and social memory of the reader. However, similar to cognitive approaches to fictive experience, such as Caracciolo's and my investigation of a subjective reader experience, will be balanced by a more formalistic approach, using stylistics and narratology to inform how the literary aesthetics operate more in detail and how they indeed create the possibilities of childhood experience. I mainly use Gérard Genette's narratological taxonomy for this purpose.

\section{The Waves of Childhood (The WaVEs)}

The deeply profound symbolism of water, sea, and especially waves has attracted human thought for ages through their associations with both the repetitiveness and passing of time. The waves' notion of change and obfuscation, and their relation to very basic natural elements, made them appropriate both as the title and the essential motif in Woolf's The Waves, a novel deeply engaged with the topic of time. The interludes describing the changing character (different waves) of an unchangeable entity (waves) remind the reader of the paradox of the passing of life and the universe's circle of life through death and resurrection. This reinforces the sense of the individual fate of one life, and the insignificance of this one life in a cosmic perspective. Waves stimulate a backtracking activity since they erase our marks in the sand and thus our own identities. Woolf manages to give her waves both a detailed material form and a symbolic value:

The sun had not yet risen. The sea was indistinguishable from the sky, except that the sea was slightly creased as if a cloth had wrinkles in it. Gradually as the sky whitened a dark line lay on the horizon dividing the sea from the sky and the grey cloth became barred with thick strokes moving, one after another, beneath the surface, following each other, pursuing each other, perpetually.

As they neared the shore each bar rose, heaped itself, broke and swept a thin veil of white water across the sand. The wave paused, and then drew out again, sighing like a sleeper whose breath comes and goes unconsciously. (3)

The analogy to the human activity of breathing forces the reader to associate these waves with life, in addition to the other associations s/he may make. Moreover, the analogy also relates to children, or children sleeping, and how we as adults listen to their breaths, which is highly appropriate since these waves are supposed to symbolize the aging of the human being. Accordingly, we meet the protagonists as children when their heartbeats resemble "thick strokes moving" and potently sweeping "a thin 
veil of white water across the sand." When the protagonists are older the waves also illustrate their older age as in this example of late middle age:

Red and gold shot through the waves, in rapid running arrows, feathered with darkness. Erratically rays of light flashed and wandered, like signals from sunken islands, or darts shot through laurel groves by shameless, laughing boys. But the waves, as they neared the shore, were rubbed of light, and fell in one long concussion, like a wall falling, a wall of grey stone, unpierced by any chink of light. (117)

The late middle age waves are contrasted to the childhood waves (relatively light descriptions of childhood with smoothing and calm words, and waves that emancipated out of the sky as the sun rose) in a remembrance of those early waves. The brightness of the early waves is hinted at in the description of rays of light that flash and wander erratically and the loss of childhood is established in the metaphor of "signals from sunken islands," as well as in the reference to "laughing boys." Through the sunset's colours and a wandering light, which abruptly ends, we enter the reality of old age: the dark waves that are passionless and motionless. The last sentence in the book is even robbed of any kind of life, or at least prosaic life: "The waves broke on the shore" (167).

The idea of waves as a symbol is not novel at all, and precisely because of that, it tends to function as a representation for the tragic and melancholic ingredients of life. The genius of The Waves lies in the way the image of the waves alters and echoes the past images of the waves in order to contemplate the passage of time. The sensation of the waves also infiltrates the whole rhythm of the book, which further enhances its nostalgic potential. "I am writing to a rhythm, not to a plot" (Woolf, A Reflection of the Other Person 204), Woolf noted, and in fact the novel's tempo is governed by the rhythm of the waves. One could say that Woolf's style is an undulating style, and it is not only in the novel's general structure, as in the recurring interludes, that we find this rhythm but also in the text itself. The rhythm of the first waves, "thick strokes moving, one after another, beneath the surface, following each other, pursuing each other, perpetually" (3), can be likened to how the characters are introduced in a rhythmic fashion that resembles these first waves:

"I see a ring," said Bernard, "hanging above me. It quivers and hangs in a loop of light."

"I see a slab of pale yellow," said Susan, "spreading away until it meets a purple stripe."

"I hear a sound," said Rhoda, "cheep, chirp, cheep, chirp; going up and down." 
"I see a globe," said Neville, "hanging down in a drop against the enormous flanks of some hill."

"I see a crimson tassel," said Jinny, "twisted with gold threads."

"I hear something stamping," said Louis. "A great beast's foot is chained.

It stamps, and stamps, and stamps." (Woolf, The Waves 4)

The rhythm of the waves is echoed in the use of the same opening word "I" in each sentence. Furthermore, the fact that every speaker's line is split by the word "said," the absence of descriptions of how these lines are said, and even the repetitions within Rhoda's and Louis's lines, emphasize this rhythm. In addition, the over-representation of the "s," "sh," and "ch" sounds echoes the sounds of the waves on the shore.

The initial chapter of Woolf's The Waves is a journey for the reader through the consciousness of childhood, which opens up the possibility of childhood identification and hence nostalgia. Although the six children do employ some different personal characteristics, they share a common nonlinguistic syntax. The slight variety in their respective personalities helps the reader to find one of them to identify more directly with.

Steve Pinkerton has briefly explored this idea of childhood consciousness in his article "Linguistic and Erotic Innocence in Virginia Woolf's The Waves," in which he notices the children's "infantile relation to language" (75). He discusses their wide use of catachresis that at times "[suggests] the poetic fecundity of a child's mind" (75). It is an accurate description of a style that creates the odd and liberated metaphoric world of a child who has to make up their own language in order to communicate, or understand phenomena yet unknown to them. Thus, leaves "are gathered round the window like pointed ears" (Woolf, The Waves 4), and when "the smoke rises, sleep curls off the roof like a mist" (5), "[b] ubbles form on the floor of the saucepan" (5), and "the tablecloth, [is] flying white along the table" (5).

The use of poetic catachresis is but one aspect of the childhood consciousness in the first chapter. Also notable is the microscopic view that the children possess, and how disjointed one impression is from another. The microscopic aspect creates a world of wonder and a world where sensations come before intellect. This becomes immediately apparent in the first six soliloquies.

Each impression is embedded either with "I see" or "I hear," and this immediately establishes the importance of the sensual aspect of the impression. Colours, shapes, and sounds, usually described with onomatopoetic words, catch the children's imagination. The impressions are unrelated, and the exact impression they are trying to convey is still uncertain. The use of "I" not only forces the reader into the subjectivity of each child, but also illustrates 
how isolated each individual subjectivity is, because communication with other children is not yet developed. This isolation of each child changes immediately in the second round of impressions when this imminent "I" is abandoned for a communicative word. "Look at the spider's web on the corner of the balcony" (4) is what Bernard says to the others. This means that the other impressions are constructed within the same space, the garden, and are still very much filtered through the different children's minds. We also notice this change from an isolated subject experiencing sensations into a subject aware of its own body. "Stones are cold to my feet" (4) says Neville, and this is countered by Jinny's sensation: "The back of my hand burns . . . but the palm is clammy and damp with dew" (4). It is not only the syntax of children that gives the impression of early childhood; it is also the choice of impressions that carry childhood and nostalgic weight in their remarkable detail.

We also notice the duration of the impressions, which start out small and then become more entangled with other impressions. A couple of pages later Jinny expresses a line of thought that is a fast development from the first isolated impressions:

"I was running," said Jinny, "after breakfast. I saw leaves moving in a hole in the hedge. I thought, 'That is a bird on its nest.' I parted them and looked; but there was no bird on a nest. The leaves went on moving. I was frightened. I ran past Susan, past Rhoda, and Neville and Bernard in the tool-house talking. I cried as I ran, faster and faster. What moved the leaves? What moves my heart, my legs? And I dashed in here, seeing you green as a bush, like a branch, very still, Louis, with your eyes fixed. 'Is he dead?' I thought, and kissed you, with my heart jumping under my pink frock like the leaves, which go on moving, though there is nothing to move them. Now I smell geraniums; I smell earth mould. I dance. I ripple. I am thrown over you like a net of light. I lie quivering flung over you." (6)

As Pinkerton observes, now the use of "I" coincides with the use of "my" which "negotiate the self as both subject and object of desire" (Pinkerton 76). The sequence above shows a development towards more prosaic language-gone is the catachresis and the fragmented manner of perception. In its place is self-knowledge and an awareness of their own physiques. The description of the first innocent kiss is very precise in its consequences.

Although the prose becomes more "ordinary" as we follow the development of the children, their particular childhood perceptions prevail. Reading the first two chapters is an experience of the process of a child maturing. As the six children represent six different personalities, there 
are further possibilities for childhood identification. This reading process makes it possible to experience nostalgia through the strong emotional reminder of one's own childhood.

\section{The Sensational Palace of Childhood (The Ice Palace)}

The most important factor that creates a childhood consciousness in Tarjei Vesaas' The Ice Palace is undoubtedly the extensive use of free indirect style (FIS) in order to capture the inner world of the two children, mainly that of Siss. Through the use of FIS, the world of the children or childhood is communicated through a similar, but less radical, focalization as we have seen in The Waves. The lack of rationality, limitations in expression, simplicity, repetitions, and a dense detailed experience of the physical, form the base for childhood identification.

Michael J. Toolan writes about FIS that it "has formal characteristics which seem to locate it somewhere between direct and indirect speech: it retains the back-shifted tenses and third-person pronouns of indirect speech, but 'freely' dispenses with any framing introductory clause (such as he thought, she said)" (74). ${ }^{4}$ FIS is described by Genette as a narration when "the narrator takes on the speech of the character, or, if one prefers, the character speaks through the voice of the narrator, and the two instances are then merged" (174). This is contrasted with the stream of consciousness, or what Genette names immediate speech, where "the narrator is obliterated and the character substitutes for him" (174).

FIS is more effective in conveying the nostalgic childhood experience than a traditional stream of consciousness narration because of its unusual sensation of a mixture between the real and the unreal, between reality and dream. This stems from the intimacy of FIS while at the same time it retains the use of third person narration. When one reads the subject "she" one is eventually assured that this "she" is in fact "I." The narration in The Ice Palace mixes factual events and enters into FIS without any warning. For example, on the very first page we are transported into FIS only through the use of the word "thoughts":

She gave a start. A loud noise had interrupted her thoughts, her expectancy; a noise like a long-drawn out crack, moving further and further off, while the sound died away....

4 For an extensive discussion of how FIS resides between temporal units, see Erlich and Raybould. 
Biting cold. But Siss was not afraid of the cold. It wasn't that. She had started at the noise in the dark, but then she stepped out steadily along the road. $(7-8)$

"She gave a start" can refer to an action, but also expresses that she felt startled. The use of "her thoughts" clearly indicates that we are and have been inside her consciousness. The thoughts that were interrupted were that she "was on her way ... to something unfamiliar, which was why it was so exciting" (7). The extensive use of sensational descriptions, as in The Waves, is already declared by the rather specific description of the sounds of the ice from the lake. Sentences are generally short and somewhat fragmented in order to show the fragmented but poetic world of the child. Even a phrase as short as "[b] iting cold," where there is a lack of subject and verb, confirms both that this is what she feels and what she thinks. These two words are the ones one would use if one thought out loud that, indeed, it was biting cold. The mystery and the irrational are then unfolded through a phrase such as "[i]t wasn't that."

The apparent, but subtle, perception of the child can be seen in a phrase such as "[a] untie seemed to be talkative" (18). A non-focalized narrator would hardly use the word "seemed" since s/he would know if she was talkative or not. Obviously, we find this kind of expression in classic narration, but in this case the "seemed" appears to indicate the way that Siss is experiencing Auntie.

The children's experience of the world is brimming with repetitions. Instead of using different expressions or synonyms as a normal writer would, the repetitions illustrate the limitations within their consciousness to experience the world in a diverse and complex way. They also connect, poetically, situations and feelings with each other, especially when these are forceful. Thus we find the odd phrase "gleams and radiance" repeated four times in one paragraph when Siss and Unn are looking at themselves in the mirror (23), and Siss repeatedly refers to her fear of the dark as something that is "at the sides of the road" (32-34) while she heads home from Unn in the night.

Likewise, in the cardinal chapter "The Ice Palace" when Unn meets her fate in the ice formation at the waterfall commonly referred to as the Ice Palace, her experience is conveyed with greatest emotional strength through her observant senses, as well as through the limitations of her language. "The black lake" and "rime-white trees," and close variations on these, occur regularly within this chapter, as well as a return of the previous "gleams and radiance."

The simulation of children's rationale is to be found here as well. It can be simple things such as a forest being "hostile" or a fear of falling 
"down into a hollow where the shadows were" (45) where the odd and charged words "hostile" and "shadows" communicate this rationale. The chapter also simulates a child's line of thinking as when Unn is meditating upon why she could not go to school:

It was no use sitting down and saying that she didn't want to go to school. Auntie would never accept that. It was too late to say she was ill too-besides, she was not in the habit of making excuses. She looked at herself quickly in the mirror: she did not look the least bit ill, it was no use telling fibs. She would leave for school as usual, and then make off before she met anyone. Make off and hide until school was over. (38)

First and foremost this chapter echoes the sense of the microscopic experience we saw in The Waves, where the details of sensation predominate as in the description of the ice on the lake:

Even the bottom was white with rime and had the thick layer of steel-ice on top of it. Frozen into this block of ice were broad, sword-shaped leaves, thin straws, seeds and detritus from the woods, a brown, straddling ant-all mingled with bubbles that had formed and which appeared clearly as beads when the sun's rays reached them. (42)

Here the sentences are much longer, since this is not a fragmented experience but a series of impressions tied together either in the thought process or in the chronology in which Unn sees these things. The use of sounds to evoke the impression of the waterfall becomes an elegant transition from far to near. It starts with a "distant roar" (45) and the assertion that you are "not supposed to be able to hear the falls from here" (45). Then the stream's "noiseless water beg[ins] to whisper" (45), later making "more noise" (46) until it "surge[s] more loudly" (46) and the roar suddenly is much "stronger" (47). When she gets closer to the falls, the sounds become more onomatopoetic. There is a "booming" (48) and the "water dashe $[\mathrm{s}]$ itself into white foam" (48) and "plunge[s] down in the middle" (48).

In much the same way as in The Waves, our experience of the world through the consciousness of the children allows for identification with the world of the child and thus our own childhood. This effect is achieved by using repetition, free indirect speech, as well as internal focalization in addition to a deliberate sensorial aesthetics. 


\section{The Sounds And Smell of Childhood \\ (THE SOUND AND THE FURY $)^{5}$}

In the first section of The Sound and the Fury, Faulkner creates an equally potent childhood experience as we have seen in the two previous examples. The first section of the novel tells the tale of Benjamin "Benjy" Compson, a mentally disabled man, during 7 April 1928. The section is focalized entirely from Benjy's perspective and is an example of unconditional stream of consciousness as sensations, associations and memories enter into his consciousness randomly and non-linearly throughout the section. Although Benjy is not a child, his perception of the world is that of a child's due to his mental impairment. Several aspects of Benjy's section in The Sound and the Fury create the possibility of childhood identification. I will list them one after another, dividing them into sections of: "Hyperbolic Sensorial Memory," "Perceptual and Cognitive Limitations of Childhood" and "Childhood Spatiotemporality."

\section{HYPERBOLIC SENSORIAL MEMORY}

The focused and hyperbolic materiality of a childhood obsession (and memory) is mainly represented by the recurring image of Benjy's "lost" sister Caddy. Throughout the section, Caddy permeates Benjy's mind. Her appearance is accentuated through Benjy's lack of synonyms. Irena Kałuża states: 'Benjy's beloved sister is always 'Caddy', whether she is seven or nineteen years old" (49). Being the child he is, his emotional reaction to Caddy's absence is sudden grief, or "bellowing." While Caddy is just temporarily gone, this grief is short and ends upon her return. When she disappears, this grief must turn into trauma. However, since Benjy has no concept of time, he does not understand how long she has been gone, and that she will never return. This results in a permanent clash between hope and despair. That is perhaps the reason why his present is invaded suddenly and abruptly by memories of his sister, even though for Benjy these memories do not appear as memories but as present states.

The abrupt memories, usually_but not always-signalled by the change of normal font to italics, seem strong and very vivid in their

5 Caracciolo performs an analysis of consciousness-enactment of the opening paragraphs in The Sound and the Fury, an analysis he calls a "Slow-Motion Analysis" (118) in how he studies this text from a micro-analytical perspective. His analysis is preoccupied with in what ways the reader could enact Benjy's consciousness. The reason I do not involve his brief analysis more in my own reading is because I want to pursue the consequences of this enactment in terms of a fictive childhood experience rather than dwelling on the very nature of consciousness-enactment. 
involuntary capacity. Ross and Polk note that the temporal transitions are often guided in a Proustian manner from one sensation to another (1011). In the novel's first time change, it is the action of getting caught in the fence that transports Benjy into an earlier episode with Caddy:

We went along the fence and came to the garden fence, where our shadows were. My shadow was higher than Luster's on the fence. We came to the broken place and went through it.

"Wait a minute." Luster said. "You snagged on that nail again. Can't you never crawl through here without snagging on that nail." Caddy uncaught me and we crawled through. (2)

This is different from Proust's method, where the narrator simplifies the time shifts by commenting on them. We are guided here only by the italic font. The actual doubling of human memory functions through associations or motivators and gives us a more physical, direct and childlike presence of memory and recollection. The physical presence is further aided by the use of a wide range of non-visual senses in describing forcefully the strength of the pasts, primarily through smells and sounds. Benjy rather smells or hears the past, than understands it: Caddy reminds him of the smell of trees, or leaves, pigs smell like pigs rather than look like pigs (28), trees are buzzing (30), father smells like rain (53), and Benjy hears the roof (55). This underlines the general sensorial aspects of memories in the way they are mainly associated with the non-visual senses.

Nevertheless, Benjy's narrative is also highly visual, rather than verbal (except dialogue), and almost "cinematic" (Polk 145). If we look at the very first sentence: "Through the fence, between the curling flower spaces, I could see them hitting" (Faulkner 1), the visual aspect comes through in the "curling flower spaces." Later Benjy does not only see a flag but he also sees how it "flapped on the bright grass and the trees" (1).

\section{PERCEPTUAL AND COGNITIVE LIMITATIONS OF CHILDHOOD}

The way that Faulkner narrates Benjy's perceptual and cognitive limitations are similar to Woolf's strategies in the opening chapters of The Waves. Like children's, Benjy's incapacity to link one thing with another, is replicated in the prose, since the lack of cause and effect is obvious. Benjy sees "them hitting," but not what they are hitting. The omission of the ball is central. Two sentences later, "Luster was hunting in the grass by the flower tree," but what is he hunting? Benjy's lack of perspective is also apparent. As Ross and Polk notice, when the golfers are further away, Benjy experiences them as "small rather than as distant" (10), communicated by Faulkner as "[t]hey were hitting little" (1). 
The repetitious prose, as we have seen in The Ice Palace, also reinforces the simplicity of childhood, and the somewhat limited perspective of the world is simulated through these repetitions and the use of a reduced number of words and expressions, such as "smells like rain" and a reoccurring symbol like "fire." When Benjy sees something twice, it gives him the same impression (the narrative often using the same words). On the first page, certain images are repeated. The fence is mentioned eight times. The flag is mentioned five times, but the description of it is exactly reproduced twice: "flapped on the bright grass and the trees." The flower tree or flower space is mentioned four times. Thus, the repetitious nature of the Benjy's section, with not only the imagery repeated, but also the simplicity of language, certain mantras, the physicality of the events, all become repetitions internalized by the reader constantly forcing them into the experience of the simple world of childhood.

\section{CHILDHOOD SPATIOTEMPORALITY}

Even though we can, through the use of italics, make distinctions between the scenes from 7 April 1928, and the other fifteen located times in the section, they seem appropriately muddled together, almost creating a sense of timelessness, atemporality, perhaps even a sort of hypothetical time. It is truly a Bergsonian time flux, where the past times flow over us involuntarily and unexpectedly. Donald M. Kartiganer writes that " $[t]$ he quality of Benjy's memory is the chief indicator of his nonhuman perception, for he does not recollect the past: he relives it" (365). It is human rather than non-human, as it is through subjective time that we capture the human sensations of temporalities. Polk addresses an important issue, when he acknowledges that Benjy "does not use words; he does not tell us things, but experiences the world directly" (145). Through Benjy's experience, narrated mimetically rather than diegetically, readers do have the possibility of sharing this kind of immediate experience. Although this kind of experience, and the flux of temporalities, is not reserved for children's perception of the world, the associative and sense-based way of being in the world is usually related to that of a child's lesser cognitive structure of time and duration.

The ambiguity of temporality as seen in the main structure of Benjy's section is further established on its micro level. At a first reading it seems that scenes from 7 April 1928, are conveyed mainly through the use of progressive forms. Benjy's account starts with "I could see them hitting" and " $[\mathrm{t}]$ hey were coming toward" (Faulkner 1). We are, of course, lacking time indicators since Benjy's experience of the world is void of traditional time markers due to his deprivation of an ordinary sense of temporality and 
spatiality. As with the use of FIS in The Ice Palace, past progressives are very appropriate for conveying a nostalgic tone, since they have this unique mix of temporalities in the tense itself. The use of past progressives does signal a temporality somewhere in between the past and the ongoing present; it does not completely belong to a past event, but it is not entirely a present activity either. Frances $\mathrm{O}$. Austin actually claims that the ambiguity of past or present time naturally leads to something "out of time" ("Ing forms in Four Quartets" 24). In his study of the past progressives (and present participles) in T. S. Eliot's Four Quartets he concludes in a reply to Peter Barry that Eliot uses them as representation of "Eternity-which he sets against the time of clock and calendars" ("Making Sense of Syntax: A Reply to Peter Barry" 167). This sense of "out of time" makes past progressives very appropriate for conveying a nostalgic childhood tone, since they have this unique mix of temporalities in the tense itself.

The use of past progressives also makes scenes visual, actualizing a feeling that it is happening before us. This is confirmed by Toolan as he observes that

progressives are not swiftly passed over in the process of reading the text. The co-occurring adjuncts help to retain the reader's attention, elaborating upon those predicates and their implications, and diverting the reader yet further from the linear sequence of events ordinarily signaled by a succession of non-expanded predicates in simple past tense. (113)

What Toolan means by retaining the reader's attention is what Michael Hogan suggests as being an "immediacy," an "immersion in the flux of the moment, and suspension within a single moment of time" that creates a dreamlike quality (qtd. in Toolan 102).

If we study the first page more carefully, we notice that the past progressive style is not constant. The golfers suddenly were not taking out the flag, they "took the flag out" and Benjy was not holding on to the fence, he "held to the fence." Throughout this section, there is a mix between past tense and past progressive tense, further blurring the temporalities between now and then. However, if we look at the first narrative time change, we observe that we, with one exception, enter a total past tense:

Caddy uncaught me and we craweled through. Uncle Maury said to not let anybody see us, so we better stoop over, Caddy said. Stoop over, Benjy. Like this, see. We stooped over and crossed the garden, where the flowers rasped and rattled against us. The ground was hard. We climbed the fence, where the pigs were grunting and snuffing. I expect they're sorry because one of them got killed today, Caddy said. The ground was hard, churned and knotted. (Faulkner 2) 
The verbs are all past tense, except for the activities of the pigs. The present tense "stoop," "see," "expect" are all part of the dialogue of Caddy, which is referred to as something present for Benjy.

As the narrative proceeds, it becomes equally difficult to establish a difference between the narrative present and past. In the present, we are, as in the beginning, challenged by the intervening past and past progressive tenses. The past sections tend towards the past tense, but the feeling of present is then balanced through the use of the present in direct speech. However, it is noteworthy that Benjy's precarious symbolic memories, especially the ones concerning Caddy, are always in the past tense, establishing them as definitely past, even for Benjy (this is something that contradicts the sense of complete atemporality with Benjy). For example, all Benjy's recollections of the smell of Caddy are "she smelled like rain" (emphasis mine).

Entering into Benjy's consciousness is like entering into the consciousness of childhood; Faulkner's highly imaginative and experimental narration opens up a potential fictive re-experience of childhood through a style that in disparate ways communicates the sensational and cognitive limitations of childhood without depriving this experience of its poetic, fantastic and timeless dimensions.

\section{CONCLUSION}

"The nostalgic return to childhood," writes James G. Hart in "Toward a Phenomenology of Nostalgia," "is a return to the aurora of springtime, the dawn of hope" (408). Evoking childhood is perhaps the most conventional and effective way of constructing nostalgia in literary readers and this has been done throughout literary history from Romanticism to the present using tropes, symbols and metaphors. What I have explored here is an additional and less acknowledged strategy: the creation of a childhood experience through fiction. Evoking the experience of childhood is the closest to actually reliving the past childhood as we can get, and the nostalgia stems from our adult, subsequent reading position that is implicitly present through the experience. This oscillation between past and present, which is an essential aspect of nostalgia and differentiates it from ordinary remembrance, is thus not inherent in the text but in the relation between the text and the reading situation. Although this aesthetic practice is not very frequent, there are occasions, mostly in modernist narratives, when this method is being used, as the three samples included in this essay confirm. The strategies involved in establishing a fictive experience of childhood, as we have seen, extend from narratological choices such as free indirect 
style and strict focalization through a child in the narrative (which implies limitations in perception and cognitive abilities, also in linguistic terms) to the use of a child-like temporality, the hyperbolic use of phenomena, and an emphasis of the sensorial aspects of perception. Being in childhood, "the dawn of hope," is to be transported not to the actual childhood, but to the idealized place of childhood where dreams and opportunities seem endless.

\section{Works CiTED}

Agacinski, Sylviane. Time Passing: Modernity and Nostalgia. Trans. Jody Gladding. New York: Columbia UP, 2000. Print.

Austin, Frances O. "Ing forms in Four Quartets." English Studies 63.1 (1982): 23-31. Print.

---. "Making Sense of Syntax: A Reply to Peter Barry." English Studies 66.2 (1985): 167-68. Print.

Barrie, J. M. "Peter Pan" and "Peter Pan in Kensington Gardens." Ware: Wordsworth, 2007. Print.

Boym, Svetlana. The Future of Nostalgia. New York: Basic, 2001. Print. Caracciolo, Marco. The Experentiality of Narrative: An Enactivist Approach. Berlin: De Gruyter, 2017. Print.

Erlich, Susan. "Aspect, Foregrounding and Point of View." Text. Interdisciplinary Journal for the Study of Discourse 7.4 (1987): 363-76. Print.

Faulkner, William. The Sound and the Fury. London: Vintage, 1995. Print. Genette, Gérard. Narrative Discourse: An Essay in Method. Trans. Jane E. Lewin. Ithaca: Cornell UP, 1983. Print.

Hart, James G. “Toward a Phenomenology of Nostalgia." Man and World: An International Philosophical Review 6.4. (1973): 397-420. Print.

Johannisson, Karin. Nostalgia: En Känslas Historia. Stockholm: Bonnier Essä, 2001. Print.

Kałuza, Irena. The Function of Sentence Structure in the Stream-ofConsciousness Technique of William Faulkner's "The Sound and the Fury": A Study in Linguistic Stylistics. Kraków: Uniwersytet Jagielloński, 1967. Print.

Kartiganer, Donald M. "The Meaning of Form in The Sound and the Fury." "The Sound and the Fury": An Authoritative Text, Backgrounds and Contexts, Criticism. Ed. David Minter. London: Norton, 1994. 36078. Print.

Merleau-Ponty, Maurice. The Phenomenology of Perception. Trans. Donald A. Landes. New York: Routledge, 2012. Print. 
Pinkerton, Steve. "Linguistic and Erotic Innocence in Virginia Woolf's The Waves." The Explicator 67.2 (Winter 2009): 75-77. Print.

Polk, Noel. "Trying not to Say: A Primer on the Language of The Sound and the Fury." New Essays on "The Sound and the Fury." Ed. Noel Polk. Cambridge: Cambridge UP, 1993. 139-75. Print.

Proust, Marcel. På spaning efter den tid som flytt [À la recherche du temps perdu]. Trans. Gunnel Vallquist. Stockholm: Bonnier, 1993. Print.

Raybould, Edith. "Of Jane Austen's Use of the Expanded Tense Forms: One more method of approach to the problem presented by these forms." Studies in English Language and Literature: Presented to Professor Dr. Karl Brunner on the Occasion of his Seventieth Birthday. Ed. Siegfried Korninger. Vienna: Braumüller, 1957. 175-90. Print.

Ross, Stephen M., and Noel Polk. Reading Faulkner: "The Sound and the Fury.” Jackson: UP of Mississippi, 1996. Print.

Salinger, J. D. The Catcher in the Rye. London: Little, 1991. Print.

Salmose, Niklas. "'Our flame, the will-o'-the-wisp that dances in a few eyes, is soon to be blown out and will fade.' Modern Literary Nostalgia as a Death Mood." Jednak Ksiązki X.X (2018): 109-22. Print.

---. "Reading Nostalgia: Textual Memory in The Great Gatsby." The F. Scott Fitzgerald Review 12 (2014): 67-87. Print.

---. Towards a Poetics of Nostalgia: The Nostalgic Experience in Modern Fiction. Edinburgh: U of Edinburgh P, 2012. Print.

Sampson, Fay. "Childhood and Twentieth-Century Children's Literature." Childhood Studies: A Reader in Perspectives of Childhood. Ed. Jean Mills and Richard W. Mills. New York: Routledge, 2000. 61-76. Print. Santesso, Aaron. A Careful Longing: The Poetics and Problems of Nostalgia. Newark: U of Delaware P, 2006. Print.

Stevenson, Randall. "Not What it Used to be: Nostalgia and the Legacies of Modernism." The Legacies of Modernism: Historicising Postwar and Contemporary Fiction. Ed. David James. Cambridge: Cambridge UP, 2011. 23-39. Print.

Toolan, Michael J. The Stylistics of Fiction: A Literary-Linguistic Approach. London: Routledge, 1990. Print.

Vesaas, Tarjei. The Ice Palace [Is-slottet]. Trans. Elizabeth Rokkan. London: Peter Owen, 2009. Print.

Woolf, Virginia. The Letters of Virginia Woolf. 1929-1931. A Reflection of the Other Person. Vol. 4. Ed. Nigel Nicolson and Joanne Trautmann Banks. London: Hogarth, 1978. Print.

---. The Waves. Hertfordshire: Wordsworth, 2000. Print.

---. To the Lighthouse. London: Penguin, 1964. Print. 
Niklas Salmose is Associate Professor of English Literature at Linnaeus University, Sweden. He is an active member of the Linnaeus University Center for Intermedial and Multimodal Studies (IMS). He is part of the international research project "Nostalgia in Contemporary Culture" and is currently guest editor for a special issue on contemporary nostalgia for the journal Humanities. His recent publications include works on F. Scott Fitzgerald, animal horror, translation, nostalgia and modernism, nostalgia and death, Nordic Noir, Alfred Hitchcock, and the Anthropocene.

niklas.salmose@lnu.se 